\title{
Fibrin/fibrinogen degradation products in children with renal disease
}

\author{
W. S. UTTLEY, HEATHER MAXWELL, and J. D. CASH \\ From the Royal Hospital for Sick Children, Edinburgh; the Department of Child Life and Health, University of \\ Edinburgh; and the South-Eastern Scotland Blood Transfusion Service
}

\begin{abstract}
Uttley, W. S., Maxwell, H., and Cash, J. D. (1974). Archives of Disease in Childhood, 49, 137. Fibrin/fibrinogen degradation products in children with renal disease. Fibrin/fibrinogen degradation products (FDP) were measured in the serum and urine of children with various forms of renal disease. Serum FDP was raised both with nephrosis and with active proliferative nephritis. Urine FDP was rarely present in nephrosis but was significantly increased during the active phase of proliferative nephritis and also in urinary tract infection with frank haematuria. Urinary FDP correlated with total urinary protein in proliferative nephritis but not in nephrosis, nor did it correlate with serum FDP in either condition. The major application of urinary FDP determination in clinical practice is as an indicator of activity and possible response to treatment in the management of active proliferative nephritis.
\end{abstract}

The role of coagulation processes and fibrin deposition in the pathogenesis of some forms of renal disease continues to receive attention. Vassalli and McCluskey (1971) have reviewed current knowledge and emphasized that with the exception of subepithelial deposits all the histological features found in proliferative renal disease may be produced in experimental animals by a primary coagulation mechanism. Duffy et al. (1970) have suggested that the deposition of fibrin subsequent both to reduced fibrinolytic activity and to 'hypercoagulability' in minimal lesion nephrotic syndromes in children may be responsible for the deterioration of function that sometimes occurs.

Clarkson et al. (1971) have shown that in adults the urinary concentration of fibrin/fibrinogen degradation products (FDP) reflects the activity and severity of proliferative glomerulonephritis and may also act as a guide to response to therapy. These authors also stressed the unexplained periodicity of FDP excretion in individual patients and thus the necessity to obtain sequential samples. Results of similar investigations in children have not been reported, though we have already shown the close relation between maximum FDP excretion and the histological evidence of fibrin from renal biopsy

Received 18 July 1973. specimens in a combined series of both adults and children (Davison et al., 1973).

This report concerns urine FDP excretion in normal children, in those with a variety of glomerulonephritic conditions, and also in a heterogeneous group of children with acute extrarenal disease.

\section{Methods}

Samples of urine were collected in clean glass jars over a 24-hour period without added preservative or fibrinolytic inhibitors. $20 \mathrm{ml}$ aliquots were stored at $-40^{\circ} \mathrm{C}$ for subsequent analysis.

Urines were dialysed against tap water for 1 hour and then concentrated to approximately $1 / 20$ of their original volume using polyethylene glycol (Clarkson, Morton, and Cash, 1970). Nonspecific haemagglutinins were absorbed using a $25 \%$ suspension of sheep red cells in Alsever's solution (Burroughs Wellcome Ltd.) and FDP was estimated as previously described for serum samples (Uttley, Allan, and Cash, 1969) using the tanned red cell haemaglutination inhibition immunoassay. Results were expressed in $\mu \mathrm{g}$ fibrinogen equivalent per $\mathrm{ml}$ original urine volume, for the benefit of comparison with the most frequently quoted adult studies.

\section{Results}

Normal children. 19 urine samples were studied from 15 children aged from 3 months to 12 years. No urine FDP was detected in 14 of these 
TABLE I

Urine FDP in acute urinary tract infection

\begin{tabular}{|c|c|c|c|c|c|}
\hline Case no. & $\begin{array}{l}\text { Maximum urine } \\
\text { FDP }(\mu \mathrm{g} / \mathrm{ml})\end{array}$ & $\begin{array}{l}\text { Maximum urinary } \\
\text { concentration } \\
(\mathrm{mOsm} / \mathrm{kg})\end{array}$ & Clinical diagnosis & Frank haematuria & $\begin{array}{l}\text { Antibody titre to } \\
\text { cultured Esch. coli }\end{array}$ \\
\hline $\begin{array}{r}1 \\
2 \\
3 \\
4 \\
5 \\
6 \\
7 \\
8 \\
9 \\
10 \\
11 \\
12\end{array}$ & $\begin{array}{l}4 \cdot 0 \\
3 \cdot 2 \\
2 \cdot 9 \\
2 \cdot 8 \\
1 \cdot 25 \\
0 \cdot 42 \\
0 \cdot 42 \\
0 \cdot 32 \\
0 \cdot 29 \\
0 \cdot 13 \\
\text { ND } \\
\text { ND }\end{array}$ & $\begin{array}{c}785 \\
- \\
776 \\
849 \\
676 \\
900 \\
408 \\
- \\
1088 \\
878 \\
951 \\
-\end{array}$ & $\begin{array}{l}P \\
C \\
C \\
C \\
C \\
P \\
P \\
C \\
P \\
C \\
C \\
P\end{array}$ & $\begin{array}{l}\text { Yes } \\
\text { Yes } \\
\text { Yes } \\
\text { Yes } \\
\text { Yes } \\
\text { No } \\
\text { No } \\
\text { No } \\
\text { No } \\
\text { No } \\
\text { No } \\
\text { No }\end{array}$ & $\begin{array}{c}- \\
- \\
- \\
\bar{Z} \\
1 / 640 \\
1 / 2560 \\
- \\
\overline{1} \\
- \\
-\end{array}$ \\
\hline
\end{tabular}

ND, not detected; $P$, acute pyelonephritis; C, cystitis.

samples and less than $0.5 \mu \mathrm{g} / \mathrm{ml}$ was detected in the remainder.

Acute extrarenal disease. 27 urine samples were assayed from 13 children with acute bacterial or viral infection. In only one of these was FDP greater than $0.5 \mu \mathrm{g} / \mathrm{ml}$-in a child with meningococcal meningitis whose concentration was $1 \mu \mathrm{g} / \mathrm{ml}$. 9 samples were assayed from 4 children with disseminated malignant disease; the maximum recorded value was $0.45 \mu \mathrm{g} / \mathrm{ml}$. However, in 4 samples obtained from 2 infants with hypernatraemic dehydration, urine FDP values of 1.31 , $4 \cdot 15,3 \cdot 5$, and $0 \cdot 21 \mu \mathrm{g} / \mathrm{ml}$ were recorded. 20 samples of urine assayed from 3 children with idiopathic thrombocytopenic purpura all gave values of less than $0.5 \mu \mathrm{g} / \mathrm{ml}$.

Chemical tests for haematuria were negative in all these samples.

Urinary tract infection. Urinary tract infection was diagnosed on the basis of the bacterial count on a cleanly passed specimen of urine being greater than $10^{5} / \mathrm{ml}$. 34 samples were obtained from 12 children with acute infection. Urine FDP was greater than $0.5 \mu \mathrm{g} / \mathrm{ml}$ in 13 of these specimens and greater than $2 \mu \mathrm{g} / \mathrm{ml}$ in 4 . Table I gives clinical details of these patients along with the maximum values. Macroscopical haematuria was present in all patients with a urine FDP greater than $1 \mu \mathrm{g} / \mathrm{ml}$.

In 8 samples from 5 patients who had recently had their urinary tract infection eradicated, the urine FDP was lower than $0.5 \mu \mathrm{g} / \mathrm{ml}$ in all instances.

\section{Glomerulonephropathy.}

Minimal lesion. 14 cases of minimal lesion nephrotic syndrome were studied during and immediately after a first or subsequent relapse. All cases had a renal biopsy showing little or no histological change on light microscopy. Urine FDP was estimated on 116 samples, the minimum number studied in any one patient being 3 . The distribution of the values obtained is shown in Table II against urinary protein as determined by Albustix (Ames Company Ltd.). The total protein content was assayed by the biuret method in 34 separate samples. No correlation was recorded between the total protein and urinary FDP content $(y=0 \cdot 17+$ $0.0002 x, r=0 \cdot 18$ ).

The mean serum FDP on 34 samples was 14.9 $\mu \mathrm{g} / \mathrm{ml} \pm 13.5 \mathrm{SD}$, being significantly higher than the normal $(10 \cdot 9 \pm 4 \cdot 3)$ (Uttley et al., 1969) $(\mathrm{t}=2 \cdot 72$,

TABLE II

Urine FDP and degree of albuminuria in minimal lesion (14 patients)

\begin{tabular}{|c|c|c|c|c|c|c|c|}
\hline \multirow{2}{*}{$\begin{array}{l}\text { Urine FDP } \\
(\mu \mathrm{g} / \mathrm{ml})\end{array}$} & \multicolumn{6}{|c|}{ Albustix } & \multirow{2}{*}{ Total } \\
\hline & - & $\mathrm{Tr}$ & + & ++ & +++ & ++++ & \\
\hline $\begin{array}{c}0-0.49 \\
0.5-0.9 \\
1.0-1.9 \\
>2.0\end{array}$ & $\begin{array}{r}27 \\
2 \\
0 \\
0\end{array}$ & $\begin{array}{l}4 \\
3 \\
0 \\
2\end{array}$ & $\begin{array}{r}15 \\
0 \\
1 \\
0\end{array}$ & $\begin{array}{r}27 \\
2 \\
0 \\
0\end{array}$ & $\begin{array}{r}29 \\
2 \\
0 \\
0\end{array}$ & $\begin{array}{r}14 \\
5 \\
3 \\
0\end{array}$ & $\begin{array}{r}116 \\
14 \\
4 \\
2\end{array}$ \\
\hline
\end{tabular}


$0.01>P>0.001)$. A maximum serum FDP of 48 $\mu \mathrm{g} / \mathrm{ml}$ was obtained in each of 3 patients while oedematous. These patients did not appear to differ clinically at this stage of their illness from the others in the group and exhibited no overt thrombotic phenomena.

There was no significant correlation between the urine FDP and serum FDP $(y=0.15+0.001 x$, no. $=15, r=0.05)$ in this group.

Henoch-Schönlein purpura. 16 patients with this syndrome were studied. 11 of these had haematuria and/or proteinuria indicative of glomerular involvement, but only 4 had renal biopsies. 3 of these biopsies showed focal proliferative nephritis and the fourth exhibited epithelial crescents in approximately $50 \%$ of glomeruli. The distribution of urinary FDP values is shown in Table III. The two values greater than $1 \mu \mathrm{g} / \mathrm{ml}$ were both obtained from the patient exhibiting epithelial crescents. There was no significant difference in FDP excretion between those patients having haematuria or proteinuria and those with no urinary abnormalities, either in respect of Student's ' $t$ ' test on the group means or with nonparametric testing (Mann-Whitney $U$ test) on the highest urine FDP of each individual patient.

The serum FDP was $9 \cdot 37 \pm 7 \cdot 20 \mathrm{SD} \mu \mathrm{g} / \mathrm{ml}$ in 28 samples from 13 patients and did not differ from the normal range.

\section{Proliferative nephritis.}

Inactive. 16 cases were seen on account of persistent or recurrent haematuria and were studied for 6 to 12 months after the onset of signs. Creatinine clearance was normal in all and proteinuria was less than $0.5 \mathrm{~g}$ daily. Biopsy findings in all cases were of focal endothelial or mesangial cell proliferation, and their lesions were regarded as being inactive or only slowly progressive in nature. A minimum of two specimens was studied in each patient. The highest urine FDP seen in this group was $1.29 \mu \mathrm{g} / \mathrm{ml}$ and the distribution of values is shown in Table III.

Active. 4 cases were studied early in the course of their illness after presenting with nephrotic oedema in addition to haematuria. These cases were regarded as being active because of proteinuria greater than $1 \mathrm{~g}$ daily, hypoproteinaemia (4 cases), and diminishing creatinine clearance ( 2 cases). Histological changes in the renal biopsy were more severe than in the inactive group. The maximum urine FDP in the patient with mesangio-capillary nephritis was $2.01 \mu \mathrm{g} / \mathrm{ml}$; in the patient with diffuse endothelial and mesangial cell proliferation with increase in mesangial matrix it was $6.2 \mu \mathrm{g} / \mathrm{ml}$; in the patient with diffuse endothelial proliferation with marked thickening of capillary basement membrane due to fibrin deposition it was $3.6 \mu \mathrm{g} / \mathrm{ml}$; and in the fourth patient with mild to moderate endothelial cell proliferation with focal thickening of capillary walls, it was $2 \cdot 95 \mu \mathrm{g} / \mathrm{ml}$.

The overall distribution of urine FDP is shown in Table III. The active group mean did not differ significantly from other disease states due to the large number of negative urines obtained. Nevertheless, nonparametric testing of the individual maximum urine FDP content in these patients against other groups (Mann-Whitney U test) shows a highly significant increase.

Fig. 1 and 2 illustrate both the periodicity of FDP

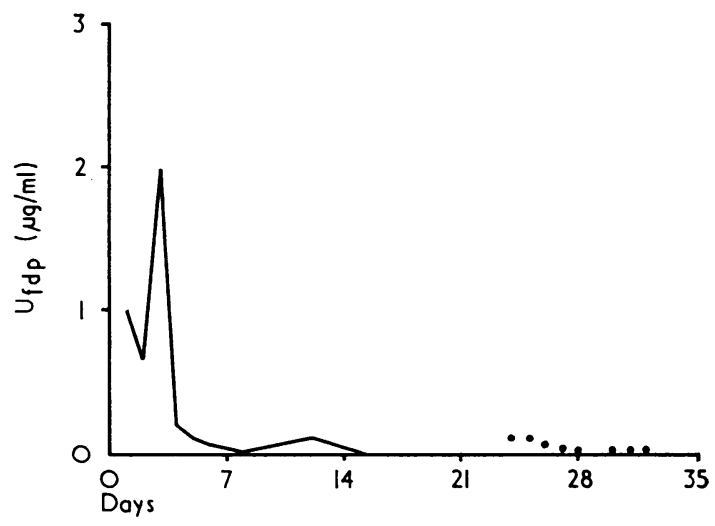

Fig. 1.-Pattern of FDP excretion in a 7-year-old boy at onset of mesangio-capillary proliferative nephritis.

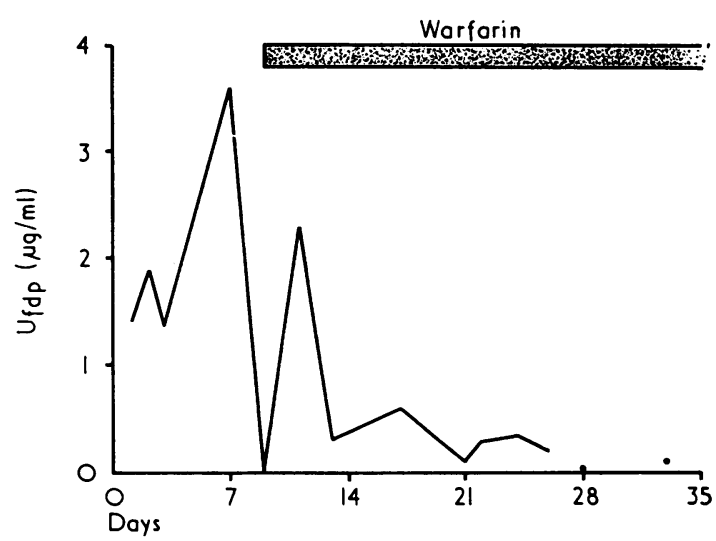

FIG. 2.-Pattern of FDP excretion in a 7-year-old girl before and during treatment with oral anticoagulants for a nephrotic syndrome due to a mild proliferative nephritis with widespread fibrin deposition shown by electron microscopy within the capillary walls. 
Distribution of urine FDP ca्de

\begin{tabular}{|c|c|c|c|c|}
\hline & Control $^{\star}$ & Nonrenal disease & $\begin{array}{l}\text { Acute urinary } \\
\text { tract infection }\end{array}$ & 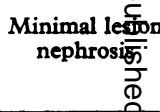 \\
\hline No. of patients & 18 & 20 & 12 & 14 (N) \\
\hline $\begin{array}{l}\text { Urine FDP }(\mu \mathrm{g} / \mathrm{ml}) \\
0-0 \cdot 49 \\
0 \cdot 5-0 \cdot 99 \\
1 \cdot 0-1 \cdot 99 \\
2 \cdot 0-5 \cdot 0 \\
>5 \cdot 0 \\
\text { Mean } \pm \text { SD } \\
\text { Highest concentration per patient } \\
\text { Mean } \pm \text { SD } \\
\text { Median } \\
\text { Range }\end{array}$ & $\begin{array}{c}39 \\
0 \\
0 \\
0 \\
0 \\
0 \cdot 05 \pm 0 \cdot 14 \\
\text { ND } \\
\text { ND } \\
\text { ND- } 0 \cdot 44\end{array}$ & $\begin{array}{c}34 \\
0 \\
3 \\
2 \\
0 \\
0 \cdot 37 \pm 0 \cdot 87 \\
0 \cdot 61 \pm 1 \cdot 14 \\
0 \cdot 12 \\
\mathrm{ND}-4 \cdot 15\end{array}$ & $\begin{array}{c}21 \\
6 \\
3 \\
4 \\
0 \\
0 \cdot 41 \pm 0 \cdot 68 \\
0 \cdot 98 \pm 1 \cdot 34 \\
0 \cdot 32 \\
N D-4 \cdot 0\end{array}$ & 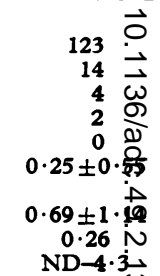 \\
\hline
\end{tabular}

^Control includes 3 patients with idiopathic thrombocytopenic purpura. ND, not detected.

excretion and the tendency for it to be greatest during the initial and presumably progressive phase of the illness, only to fall as activity subsides and healing occurs.

Fig. 1 refers to a 7-year-old boy with an early mesangio-capillary proliferative nephritis receiving no treatment other than bed rest and penicillin. Conversely, Fig. 2 shows a similar pattern of FDP excretion in a 7-year-old girl with mild diffuse proliferation of mesangial cells with marked fibrin deposition in basement membrane during treatment with oral anticoagulants.

Serum FDP was increased in the active group as compared with the inactive cases and with normal children. Paired samples from both proliferative groups showed a correlation between urine FDP and total urinary protein as estimated by the biuret method $(y=0.63+0.001 x$, no. $=21, r=0.64$, $P<0.01)$. There was no correlation between urine FDP and serum FDP $(y=0 \cdot 19+0 \cdot 02 x$, no. $=22$, $\mathbf{r}=0.04)$.

\section{Discussion}

These results show that in health normal children do not excrete quantities of FDP greater than 0.5 $\mu \mathrm{g} / \mathrm{ml}$ and in the majority it is undetectable by the method used.

Clarkson et al. (1971) suggested that urine FDP levels greater than $2 \mu \mathrm{g} / \mathrm{ml}$ were associated with active proliferative nephritis. In these patients raised excretion rates were primarily due to $D$ and $E$ fragments (late degradation products of low molecular weight), while the incompletely degraded early products ( $\mathrm{X}$ and $\mathrm{Y}$ ) accounted for the raised urine FDP observed in conditions of abnormal glomerular permeability, such as minimal lesion. Our limited experience of active proliferative disease in children conforms with the hypothesis that a urine FDP of greater than $2 \mu \mathrm{g} / \mathrm{ml}$ is indeed an index of activity as shown, for example, in Fig. 1 and 2. Failure to show urine FDP in increased amounts in the relatively inactive cases of persistent or recurrent haematuria provides further reassuring evidence for the relative innocence of so-called benign recurrent haematuria.

Our failure to show significant increases of FDP excretion in the Henoch-Schönlein syndrome, with or without proteinuria and haematuria, was surprising in view of the emphasis given to fibrin deposition in this condition by Habib and Levy (1972). The explanation for this may lie in the fact that the majority of such patients do not have severe renal lesions; this was the case in our series. Evidence in favour of this conclusion was available: the only case with raised urine FDP had the most severe renal involvement both clinically and histologically, even though this did not hold for the severity of the other extrarenal manifestations of the syndrome. Though it is known that glomerular abnormalities may exist in renal biopsies carried out on patients without urinary signs (Vernier et al., 1961), our data suggest that such lesions are not associated with increased FDP excretion and are hence unlikely to be of significance with regard to deterioration of renal function.

The large number of urines studied from patients with minimal lesion nephrosis failed with only two exceptions to show any significant FDP excretion, even with heavy proteinuria in excess of $5 \mathrm{~g}$ daily. Thus it appears that the deposition of fibrin 
ions in disease groups studied

\begin{tabular}{|c|c|c|c|c|c|}
\hline \multicolumn{3}{|c|}{ Henoch-Schönlein purpura } & \multicolumn{3}{|c|}{ Other forms of proliferative nephritis } \\
\hline $\begin{array}{l}\text { Proteinuria/ } \\
\text { haematuria }\end{array}$ & $\begin{array}{l}\text { Urine analysis } \\
\text { clear }\end{array}$ & Total & Active & Inactive & Total \\
\hline 11 & 5 & 16 & 4 & 16 & 20 \\
\hline $\begin{array}{c}53 \\
3 \\
1 \\
1 \\
0 \\
0 \cdot 22 \pm 0 \cdot 48\end{array}$ & $\begin{array}{c}17 \\
2 \\
0 \\
0 \\
0 \\
0 \cdot 19 \pm 0 \cdot 23\end{array}$ & $\begin{array}{c}70 \\
5 \\
1 \\
1 \\
0 \\
0 \cdot 21 \pm 0 \cdot 43\end{array}$ & $\begin{array}{c}59 \\
16 \\
7 \\
9 \\
1 \\
0.65 \pm 1 \cdot 01\end{array}$ & $\begin{array}{c}27 \\
7 \\
4 \\
0 \\
0 \\
0 \cdot 34 \pm 0 \cdot 40\end{array}$ & $\begin{array}{c}86 \\
23 \\
11 \\
9 \\
1 \\
0.56 \pm 0.89\end{array}$ \\
\hline $\begin{array}{c}0.69 \pm 0.97 \\
0.22 \\
N D-3.3\end{array}$ & $\begin{array}{c}0 \cdot 34 \pm 0 \cdot 30 \\
0 \cdot 26 \\
\text { ND-0.41 }\end{array}$ & $\begin{array}{c}0.52 \pm 0 \cdot 82 \\
0 \cdot 23 \\
\mathrm{ND}-3 \cdot 3\end{array}$ & $\begin{array}{c}3 \cdot 70 \pm 1 \cdot 8 \\
2 \cdot 95 \\
2 \cdot 01-6 \cdot 2\end{array}$ & $\begin{array}{c}0.48 \pm 0.45 \\
0 \cdot 26 \\
N D-1 \cdot 29\end{array}$ & $\begin{array}{c}1 \cdot 12 \pm 1 \cdot 55 \\
0 \cdot 59 \\
\text { ND-6.2 }\end{array}$ \\
\hline
\end{tabular}

thrombi, recorded by Duffy et al. (1970), is not a frequent occurrence and is unlikely to contribute significantly to renal function impairment in the long term. Nevertheless, there were significantly raised serum FDP levels in our patient group and this might be related to the known tendency towards thrombotic complications in nephrosis, particularly during treatment with steroids (Lieberman et al., 1968).

The present investigation sheds little light on the origin of urine FDP. The lack of correlation between urine FDP and serum FDP, despite a rise of the latter in both proliferative and minimal lesion nephropathy, is against urine FDP being derived from glomerular filtration of degradation products and agrees with other reported series. The significant correlation between urine FDP and urinary protein concentration in the poorly selective proliferative cases agrees with the findings in children by Eckert et al. (1972) and in mixed cases by Briggs et al. (1972), but not with Clarkson et al. (1971) whose studies were performed exclusively on adults. However, it seems likely from our previous work, showing a positive relation between urine FDP and the semi-quantitative assessment of the amount of fibrin within the glomerulus as seen at biopsy (Davison et al., 1973), that urine FDP is derived directly from the breakdown of fibrin deposited in the mesangial cell and/or capillary wall.

The lack of correlation between urine FDP and total protein excretion in minimal lesion nephropathy also differs from the results of Clarkson et al. (1971). Recalculation of the data (urine FDP against total urinary protein per 24 hours), for direct comparison with the figures of Clarkson et al., also showed a failure to correlate. However, the total amount of protein lost per 24 hours in our younger patients was substantially less than in Clarkson et al.'s adult series. Thus, comparison may be difficult to make. Nevertheless, it was apparent that abnormal urine FDP excretion in minimal lesion is an unusual event.

The finding of raised urine FDP in urinary tract infection is interesting in view of the recent report by Whitworth et al. (1973) showing that urine FDP levels greater than $5 \mu \mathrm{g} / \mathrm{ml}$ in adults are diagnostic of pyelonephritis as opposed to infection of the lower urinary tract, though the converse did not hold. Though we did not carry out Fairley's bladder wash-out technique (Fairley et al., 1967), there was no relation in our series between pyelonephritis as defined on the usual clinical criteria and on the concentration tests (Uttley, Paxton, and Thistlethwaite, 1972) and the amount of urine FDP. Indeed, in our series increased FDP excretion was only found in these patients in the presence of frank haematuria irrespective of the apparent site and degree of infection. This finding may also have implications regarding the derivation of urine FDP, as the source of bleeding in such cases is generally sited in the lower urinary tract (in one of our cases bleeding followed suprapubic aspiration of urine). Thus, if bleeding into the urinary tract per se was sufficient to cause these amounts of FDP excretion, then it must be assumed that bleeding from the nephron in proliferative nephropathies, most of which have haematuria, and whatever its actual pathogenesis in the nephron, must contribute significantly to the amount of urinary FDP excretion.

Our findings in acute nonrenal disease in children, 
particularly hypernatraemic dehydration, probably reflect unrecognized renal damage presumably due to renal ischaemia.

The clinical application of the estimation of urinary FDP in the paediatric age group seems to be restricted to the monitoring of potentially progressive proliferative nephropathies, regarding either activity or response to drugs (Clarkson et al., 1972), as shown in Fig. 1 and 2 . We are not convinced that it has practical application in the diagnosis and management of urinary tract infection as suggested by Whitworth et al. (1973) and it clearly has no predictive value in minimal lesion nephrosis.

This work was made possible by a grant (H.M.) from the Research Endowment Fund of the Royal Hospital for Sick Children, Edinburgh. We acknowledge the help on technical matters given by Dr. A. R. Clarkson, now Consultant Nephrologist in Adelaide, and the secretarial assistance of Miss Elizabeth Meiklejohn and Miss Ursula Burnet.

\section{REFERENCES}

Briggs, J. D., Prentice, C. R. M., Hutton, M. M., Kennedy, A. C., and McNicol, G. P. (1972). Serum and urine fibrinogen-fibrinrelated antigen (F.R.-antigen) levels in renal disease. British Medical fournal, 4, 82.

Clarkson, A. R., MacDonald, M. K., Cash, J. D., and Robson, J. S. (1972). Modification by drugs of urinary fibrin/fibrinogen degradation products in glomerulonephritis. British Medical Fournal, 3, 255.

Clarkson, A. R., MacDonald, M. K., Petrie, J. J. B., Cash, J. D., and Robson, J. S. (1971). Serum and urinary fibrin/fibrinogen degradation products in glomerulonephritis. British Medical Fournal, 3, 447.

Clarkson, A. R., Morton, J. B., and Cash, J. D. (1970). Urinary fibrin/fibrinogen degradation products after renal homotransplantation. Lancet, 2, 1220.
Davison, A. M., Thomson, D., MacDonald, M. K., Rae, J. K., Uttley, W. S., and Clarkson, A. R. (1973). Identification of intrarenal fibrin deposition. Fournal of Clinical Pathology, 26, 102.

Duffy, J. L., Cinque, T., Grishman, E., and Churg, J. (1970) Intraglomerular fibrin, platelet aggregation, and subendothelial deposits in lipoid nephrosis. Fournal of Clinical Investigation, $49,251$.

Eckert, H., Barratt, T. M., Chantler, C., and Turner, M. W. (1972). Immunologically reactive equivalents of fibrinogen in sera and urine of children with renal disease. Archives of Disease in Childhood, 47, 90.

Fairley, K. F., Bond, A. G., Brown, R. B., and Habersberger, P. (1967). Simple test to determine the site of urinary-tract infection. Lancet, 2, 427.

Habib, R., and Levy, M. (1972). Les nephropathies du purpura rheumatoide chez l'enfant. Archives Fraņ̧aises de Pédiatrie, 29, 305.

Lieberman, E., Heuser, E., Gilchrist, G. S., Donnell, G. N., and Landing, B. H. (1968). Thrombosis, nephrosis, and corticosteroid therapy. Fournal of Pediatrics, 73, 320.

Uttley, W. S., Allan, A. G. E., and Cash, J. D. (1969). Fibrin/ fibrinogen degradation products in sera of normal infants and children. Archives of Disease in Childhood, 44, 761.

Uttley, W. S., Paxton, J., and Thistlethwaite, D. (1972). Urinary concentrating ability and growth failure in urinary tract disorders. Archives of Disease in Childhood, 47, 436.

Vassalli, P., and McCluskey, R. T. (1971). The pathogenetic role of the coagulation process in glomerular disease of immunologic origin. In Advances in Nephrology, Vol. I, p. 47 . Ed. by J. Hamburger, J. Crosnier, and M. H. Maxwell. Year Book Medical Publishers, Chicago.

Vernier, R. L., Worthen, H. G., Peterson, R. D., Colle, E., and Good, R. A. (1961). Anaphylactoid purpura. I. Pathology of the skin and kidney and frequency of streptococcal infection. Pediatrics, 27, 181.

Whitworth, J. A., Fairley, K. F., McIvor, M. A., and Stubbs, A. E. (1973). Urinary fibrin-degradation products and the site of urinary infection. Lancet, 1, 234.

Correspondence to Dr. W. S. Uttley, Department of Child Life and Health, University of Edinburgh, 17 Hatton Place, Edinburgh EH9 1UW. 